\title{
Study on Fabric and Seam Strength Loss of Denim Trousers for Different Washing Treatments
}

\author{
Mohammad Rafiqur Rashid1, Mohammad Faizur Rahman ${ }^{2 *}$ \\ ${ }^{1}$ Department of Industrial and Production Engineering, Bangladesh University of Textiles (BUTEX), Dhaka, Bangladesh \\ ${ }^{2}$ Department of Textile Engineering, Ahsanullah University of Science and Technology (AUST), Dhaka, Bangladesh \\ Email: rafiqurrashid.tt@gmail.com, ${ }^{*}$ rashedtex@gmail.com
}

How to cite this paper: Rashid, M.R. and Rahman, M.F. (2020) Study on Fabric and Seam Strength Loss of Denim Trousers for Different Washing Treatments. Journal of Textile Science and Technology, 6, 114-122. https://doi.org/10.4236/jtst.2020.63009

Received: March 1, 2020

Accepted: June 14, 2020

Published: June 17, 2020

Copyright $\odot 2020$ by author(s) and Scientific Research Publishing Inc. This work is licensed under the Creative Commons Attribution International License (CC BY 4.0).

http://creativecommons.org/licenses/by/4.0/

\begin{abstract}
This paper shows that fabric and seam strength loss (\%) of the selected denim trousers occurred for different washing applications. At first, a commonly used denim fabric of $12.5 \mathrm{Oz} / \mathrm{yd}^{2}$ was selected to make the trousers containing two types of seam i.e. superimposed and lapped seam. Then bleach, enzyme and acid wash were applied on the produced trousers and fabric \& seam strength loss were determined by using related standard and equipment. It was found that fabric strength loss is higher in case of acid wash and the loss of seam strength is higher in case of enzyme wash.
\end{abstract}

\section{Keywords}

Fabric Strength, Superimposed Seam, Lapped Seam, Seam Strength, Denim Trousers

\section{Introduction}

Over the past three decades Bangladesh's RMG (readymade garments) industry has expanded rapidly [1]. This RMG sector is earning the highest foreign currency (84.21\%) among the total exports of Bangladesh [2]. So, RMG industry plays a major role in the economy of this country. The amount of foreign currency can be increased by improving product quality [3]. Denim (Jeans) washing is considered as one of the frequently used finishing treatments that have widespread use in RMG sectors due to creating a special appearance and making trendy and comfortable garments of today's world that are commonly used [4]. Due to its weaving and dyeing results, denim clothing is uncomfortable to wear without finishing treatments. For this, it basically requires a finishing treatment 
to make it wear even better, smoother and comfortable [5]. The popularity of clothing was growing day by day, particularly on denim clothing on the world market [6]. A range of treatment methods such as bleaching treatment, enzymatic treatment, acid treatment, and silicone treatment are widely used for the washing of denim garments. They all aim for new possible effects of the appearance of fabric [7]. Garments' outlook is one of the most important aspects of its consistency [8] and various chemical and mechanical treatments on readymade garments give the production of very interesting and original visual effects on their surfaces. One of the current trends in fashion is the retro look or an aged look or a distressed look for casual wear that has become very popular among young clients [9]. Acid wash on denim jeans is becoming very popular due to its striking contrasts and attractive color appearance. Indigo \& Sulfur base fabric clothes can be washed with acid. Acid washing of denim clothing is usually performed by tumbling the garments with pumice stones presoaked in a solution containing sodium hypochlorite (5\% to $10 \%$ ) or potassium permanganate (3\% to $6 \%)$ [10]. In recent years, an increasing interest has been shown in the use of environmentally friendly, non-toxic, fully biodegradable enzymes in modern textile manufacturing finishing processes. Enzymatic treatment may replace a variety of mechanical and chemical processes used to enhance the comfort and quality of the fabrics [11] [12]. In the textile industry, enzymes are primarily used to achieve a smoother, less sticky fabric sheet, to reduce the tendency to form a pill, to improve the handling and to smooth the surface, together with conventional softeners. Development studies in this area focused on the application of enzymes to cellulose materials based on cotton, linen, viscose and their blending with synthetic fibres [13]-[18]. This paper investigated the impact of bleach, enzyme and acid wash on the physical and mechanical properties of denim apparel.

\section{Material and Methods}

In the study, a denim fabric (Figure 1) which is mostly used was collected from a $100 \%$ export oriented denim industry of Bangladesh. The fabric was $100 \%$ cotton, 3/1 twill, warp count was 10/1 Ne Carded and weft yarn was Ne 12.5/1 Carded. During fabric production, the Picanol Rapier weaving machine was used and the weight of the produced denim fabric (Figure 1) was $12.5 \mathrm{Oz} / \mathrm{Yd}^{2}$.

After that samples (leg panels) (Table 1) were produced using the manufactured denim fabric (Figure 1). Mainly two types of seam (superimposed and lapped) (Figure 1) were applied in the leg panels of trousers by industrial lock stitch and feed off the arm machine. In this case, the sewing thread was 100\% spun polyester $(20 / 2 \mathrm{Nm})$ keeping other machine parameters constant. Total no. of the samples for this research was 120 . The detailed distribution of samples is stated in Table 1.

The produced leg panels were treated by bleach wash, enzyme wash and acid wash using standard recipes. The washing process was accomplished in a sample washing machine (Ngai-shing, Hong Kong). 


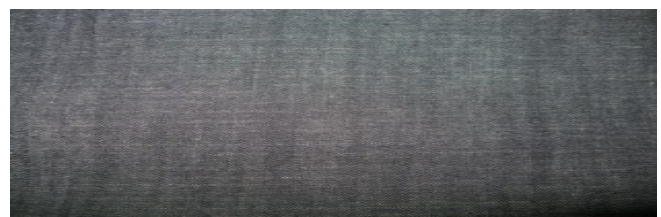

Figure 1. The fabric used in the study.

Table 1. Sample distribution for all processing.

\begin{tabular}{ccccccc}
\hline \multirow{2}{*}{ Treatment } & $\begin{array}{c}\text { No. of samples in case } \\
\text { of fabric strength test }\end{array}$ & \multicolumn{2}{c}{$\begin{array}{c}\text { No. of samples in case } \\
\text { of superimposed seam }\end{array}$} & $\begin{array}{r}\text { No. of samples in case } \\
\text { of lapped seam }\end{array}$ \\
\cline { 2 - 7 } & Warp wise & Weft wise & Warp wise & Weft wise & Warp wise & Weft wise \\
\hline Before wash & 5 & 5 & 5 & 5 & 5 & 5 \\
Bleach wash & 5 & 5 & 5 & 5 & 5 & 5 \\
Enzyme wash & 5 & 5 & 5 & 5 & 5 & 5 \\
Acid wash & 5 & 5 & 5 & 5 & 5 & 5 \\
\hline
\end{tabular}

\subsection{Bleach Wash}

The bleach wash was carried out in four steps which are pretreatment, bleaching, hot wash and neutral wash. The liquor ratio was 1:30 and hydrogen per peroxide $\left(\mathrm{H}_{2} \mathrm{O}_{2}\right)(35 \%)$ was used as bleaching agent here. In the pretreatment step, desizing agent $(2 \mathrm{ml} / \mathrm{l})$, wetting agent $(1 \mathrm{ml} / \mathrm{l})$ were used and the $\mathrm{pH}$ was maintained within 6.5 - 7. In the step of bleaching, caustic soda (8\%), $\mathrm{H}_{2} \mathrm{O}_{2}(8 \mathrm{ml} / \mathrm{l})$ and soda ash $(2 \%)$ were used. Then hot wash was applied at temperature $50^{\circ} \mathrm{C}$ and followed by a neutral wash with acetic acid $(1 \mathrm{ml} / \mathrm{l})$. After that the bleach washed sample (Figure 2) was created.

\subsection{Enzyme Wash}

The enzyme treated sample (Figure 3) was produced by following six steps which are desizing, rinse wash, enzyme treatment, rinse wash, clean up and rinse wash. The liquor ratio was 1:30 and cellulase enzyme was used as enzymatic agent here. In the desizing step, soda ash (100 gm) was used and $\mathrm{pH}$ was maintained as 8 . In $2^{\text {nd }}, 4^{\text {th }}$ and $6^{\text {th }}$ steps, rinse wash was applied in this process whereas in the $3^{\text {rd }}$ step, cellulase enzyme $(80 \mathrm{gm})$ and acetic acid $(35 \mathrm{gm})$ were used for fading the colour of the samples (leg panels).

\subsection{Acid Wash}

The soaking process of pumice stone was carried out in a bath containing potassium permanganate $\left(\mathrm{KMnO}_{4}\right)-8 \mathrm{gm} / \mathrm{l}$ and phosphoric acid $\left(\mathrm{H}_{3} \mathrm{PO}_{4}\right)-1 \mathrm{ml} / \mathrm{l}$ for 15 minutes. The solution was picked up by pumice stones very quickly as it was $90 \%$ porous. After this step, processed stones were dried in open air. Then these pumice stones were applied to the prepared samples. This treatment was continued for 30 minutes. Finally treated samples (Figure 4) were neutralized by sodium meta-bisulphite $-4 \mathrm{gm} / \mathrm{l}$ at room temperature for 7 minutes. Subsequently samples (Figure 4) were hydro-extracted and dried. 


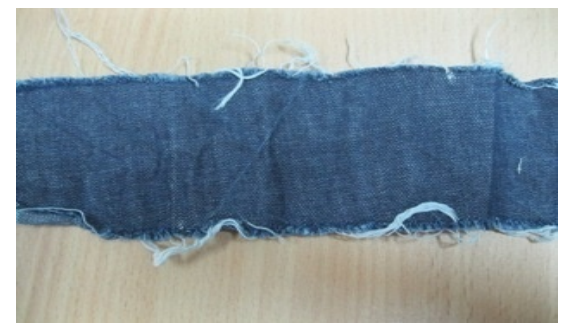

Figure 2. Bleached washed sample.

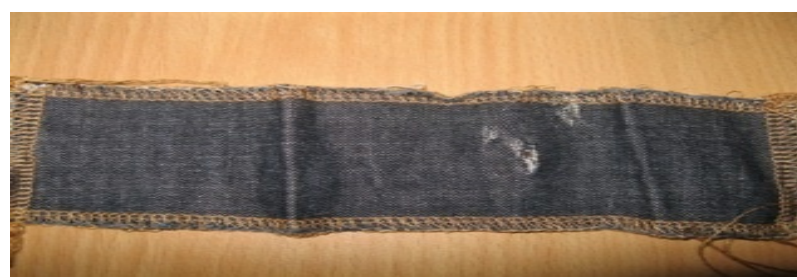

Figure 3. Enzyme treated sample.

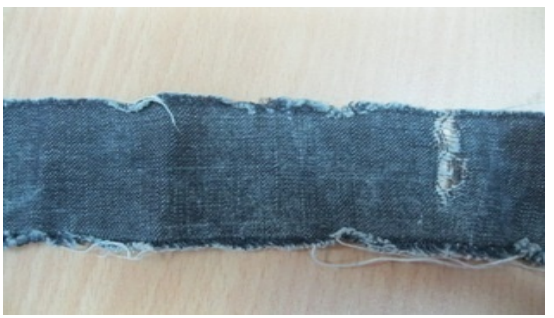

Figure 4. Acid washed sample.

\section{Testing and Analysis}

Treated all denim leg panels were conditioned in $65 \% \mathrm{RH}$ and $20^{\circ} \mathrm{C}$ temperature for 24 hours before testing. Tensile strength (breaking force) was determined by US standard grab test method according to ASTM D5034. Seam strength of samples was measured by TITAN Universal strength tester according to ISO 13935-2:2014. Experiment data of fabric strength (Table 2) and seam strength (Table 3 \& Table 4) are given.

\section{Result and Discussions}

\subsection{Effect of Apparel Washing on Fabric Strength}

The strength changes of fabric and seam of produced leg panels are as follows. Here the leg panels were treated by using bleach wash, enzyme wash and acid wash. Then the strength loss percentage (Table 5) was shown compared to the strength before applying different washes. The strength loss (Table 5) was calculated by using the following equation.

$$
\text { Strength loss }(\%)=\frac{\text { Strength before washing }- \text { Strength after washing }}{\text { Strength before washing }} \times 100
$$

Figure 5 shows that fabric strength loss $(27.73 \%)$ is higher in case of the acid wash treatment whereas fabric strength loss $(3.26 \%)$ is the lowest in case of 


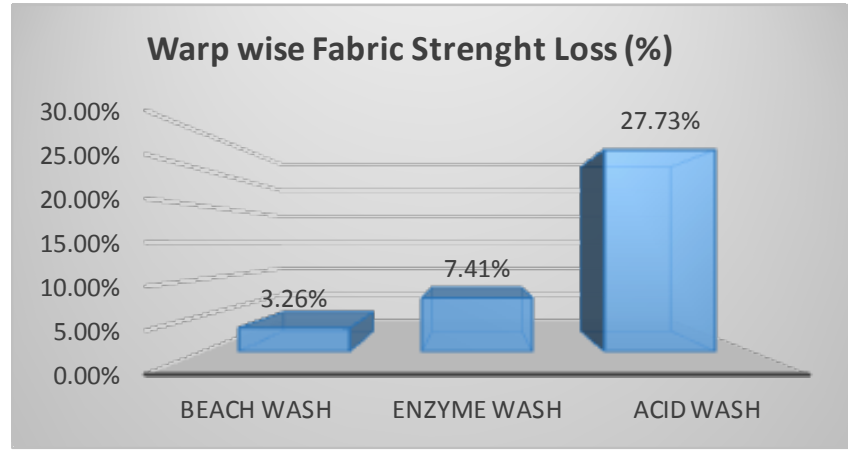

Figure 5. Warp wise fabric strength loss (\%) for different washing treatments.

Table 2. Strength of fabric (warp and weft wise) before and after wash.

\begin{tabular}{cccc}
\hline No. & Sample type & Sample direction & Maximum force (N) \\
\hline 1. & Before wash & Warp & 918.06 \\
2. & & Weft & 506.22 \\
3. & Bleach wash & Warp & 888.12 \\
4. & & Weft & 484 \\
5. & Enzyme wash & Warp & 850 \\
6. & & Weft & 474.91 \\
7. & Acid wash & Warp & 663.47 \\
8. & & Weft & 309.00
\end{tabular}

Table 3. Strength of superimposed seam (warp and weft wise) before and after wash.

\begin{tabular}{cccc}
\hline No. & Sample type & Sample direction & Maximum force(N) \\
\hline 1. & Before wash & Warp & 755.82 \\
2. & & Weft & 650.67 \\
3. & Wleach wash & Warp & 664.01 \\
4. & & Weft & 598.75 \\
5. & Enzyme wash & Warp & 692.99 \\
6. & & Weft & 479.88 \\
7. & Acid wash & Warp & 571.62 \\
8. & & Weft & 629.41 \\
\hline
\end{tabular}

Table 4. Strength of lapped seam (warp and weft wise) before and after wash.

\begin{tabular}{cccc}
\hline No. & Sample type & Sample direction & Maximum force (N) \\
\hline 1. & Before wash & Warp & 1322.33 \\
2. & & Weft & 876.71 \\
3. & Wleach wash & Warp & 1166.68 \\
4. & & Weft & 777.30 \\
5. & Enzyme wash & Warp & 882.17 \\
6. & & Weft & 665.21 \\
7. & Acid wash & Warp & 1280.30 \\
8. & & Weft & 860.03 \\
\hline
\end{tabular}




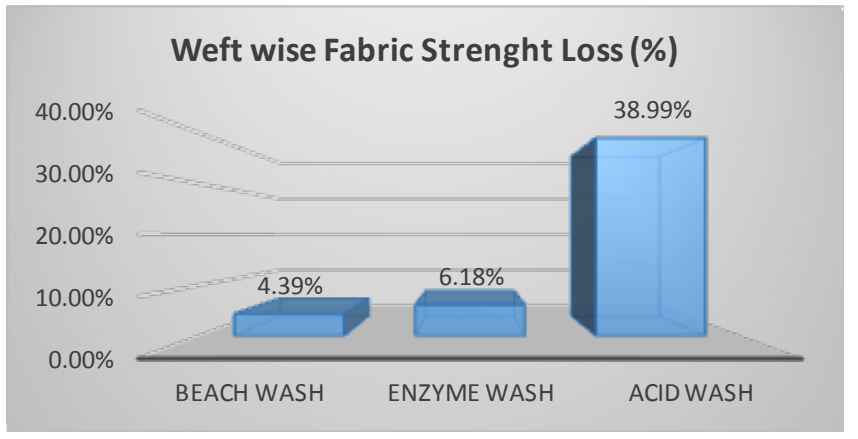

Figure 6. Weft wise fabric strength loss (\%) for different washing treatments.

Table 5. Strength loss of fabric.

\begin{tabular}{cccc}
\hline Direction & Beach wash & Enzyme wash & Acid wash \\
\hline Warp wise & $3.26 \%$ & $7.41 \%$ & $27.73 \%$ \\
Weft wise & $4.39 \%$ & $6.18 \%$ & $38.99 \%$ \\
\hline
\end{tabular}

bleach wash treatment. In acid wash acid, pumice stone and potassium permanganate are used combined so that the strength loss (Figure 5) is higher. On the other hand, only bleaching agent is used in bleach wash for which the strength loss (Figure 5) is lower.

Figure 6 indicates that fabric strength loss (38.99\%) is higher in case of the acid wash treatment whereas fabric strength loss (4.39\%) is the lowest in case of bleach wash treatment. In acid wash acid, pumice stone and potassium permanganate are used combined so that the strength loss (Figure 6) is higher. On the other hand, only bleaching agent is used in bleach wash for which the strength loss (Figure 6) is lower. Here it is also mentionable that the fabric strength loss (Figure 6) is more in case of weft direction compared to warp direction. The main reason behind this result is that EPI was more than PPI in this fabric.

\subsection{Effect of Apparel Washing on Seam Strength}

Enzyme wash has influence in the decrement of seam strength of superimposed seam (Table 6) which is clearly visible in the treated samples. The reduction in the seam strength has primarily been assisted by the friction between the stone $\&$ panels. The most significant seam strength occurred with enzyme was (Warp wise-24.37\% and Weft wise-26.25\%) (Figure 7 \& Figure 8) compared to bleach and acid wash.

The same trend exists here which was found in case of superimposed seam. In case of lapped seam the effect of enzyme wash is more significant than other two washes (bleach $\&$ acid wash). The fall in the seam strength has principally been backed by the friction among pumice stone, panels and mechanical bars of washing machine. The most changes achieved in seam strength of lapped seam (Table 7) are 33.28\% (warp wise seam strength loss) (Figure 9) and 24.12\% (weft wise seam strength loss) (Figure 10). 


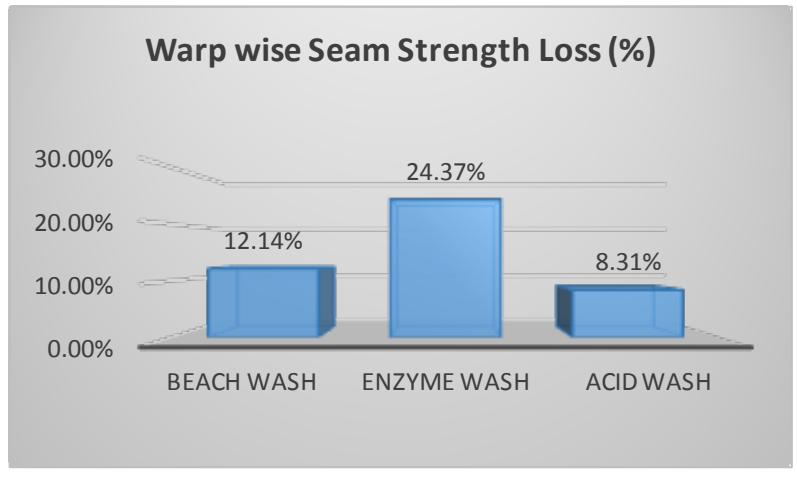

Figure 7. Warp wise seam strength loss (\%) for different washing treatments.

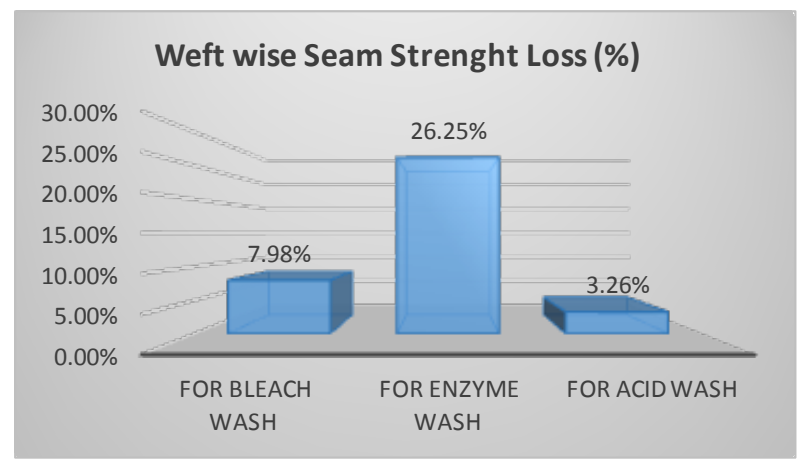

Figure 8. Weft wise seam strength loss (\%) for different washing treatments.

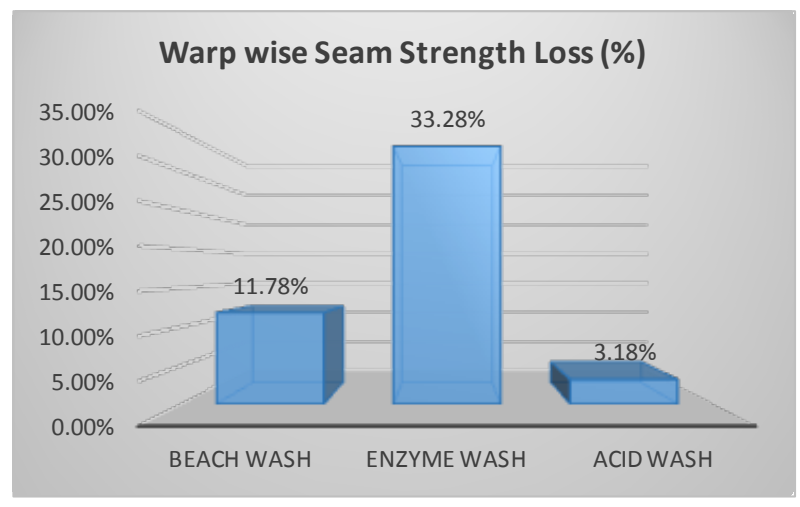

Figure 9. Warp wise seam strength loss (\%) for different washing treatments.

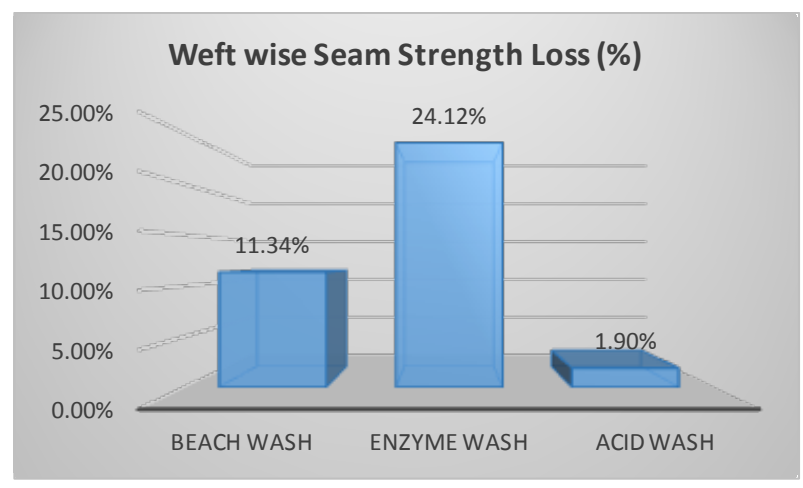

Figure 10. Weft wise seam strength loss (\%) for different washing treatments. 
Table 6. Strength loss of superimposed seam.

\begin{tabular}{cccc}
\hline Direction & Beach wash & Enzyme wash & Acid wash \\
\hline Warp wise & $12.14 \%$ & $24.37 \%$ & $8.31 \%$ \\
Weft wise & $7.98 \%$ & $26.25 \%$ & $3.26 \%$ \\
\hline
\end{tabular}

Table 7. Strength loss of lapped seam.

\begin{tabular}{cccc}
\hline Direction & Beach wash & Enzyme wash & Acid wash \\
\hline Warp wise & $11.78 \%$ & $33.28 \%$ & $3.18 \%$ \\
Weft wise & $11.34 \%$ & $24.12 \%$ & $1.90 \%$ \\
\hline
\end{tabular}

\section{Conclusion}

Outlook, comfort and fashion of garments can be changed or modified by washing. Different washing processes are used for producing different outlooks of garments. Nowadays, garment washing is a very demanding process. Basically it is a value added process for the value addition; usually it would like to go for different types of process where fabric quality as well as garment quality deteriorates. In this study, three different washing treatments were applied on trousers (leg panels) and the strength change was observed. Though the strength differs with the application of three different washing treatments (bleach, enzyme and acid wash) in this study, it is clear that the strength of fabric and seam is lower for washing treatment than that before washing. The result of this study exhibits that fabric strength loss is higher in case of acid wash and the loss of seam strength is higher in case of enzyme wash. So, it can be said that the change in strength loss of fabric and seam is significant which occurs due to the application of bleach, enzyme and acid wash on garments.

\section{Conflicts of Interest}

The authors declare no conflicts of interest regarding the publication of this paper.

\section{References}

[1] Haider, Z.M. (2007) Competitiveness of the Bangladesh Ready-Made Garment Industry in Major International Markets. Asia-Pacific Trade and Investment Review, 3, 3-27.

[2] http://www.bgmea.com.bd/home/pages/TradeInformation

[3] https://www.economicshelp.org/blog/4819/currency/how-to-increase-the-value-ofcurrency

[4] Grieve, M., Biermann, T. and Schaub, K. (2006) The Use of Indigo Derivatives to Dye Denim Material. Science \& Justice, 46, 15-24. https://doi.org/10.1016/S1355-0306(06)71563-5

[5] Khan, R.M.M., Mondol, H.I. and Uddin, Z.M. (2012) Sustainable Washing for Denim Garments by Enzymatic Treatment. Journal of Chemical Engineering, 27, 27-31. https://doi.org/10.3329/jce.v27i1.15854 
[6] Islam, M.T. (2010) Garments Washing \& Dyeing. Ananto Publications, Dhaka.

[7] Solaiman Rouf, A., Rasel, S. and Khalil, E. (2015) Investigation of Different Washing Effects on Physical and Mechanical Properties of Cotton Knitted Garments. Journal of Textile Science and Technology, 1, 101-109. https://doi.org/10.4236/jtst.2015.13011

[8] Oğulata, R.T. and Balci, O. (2007) Effects of Extra Washing after Treatments on Fastness and Spectrophotometric Properties of Dyed PET/Viscose/Elastane Fabric. Journal of the Textile Institute, 98, 409-420. https://doi.org/10.1080/00405000701475734

[9] Card, A., Moore, M.A. and Ankeny, M. (2005) Performance of Garment Washed Denim Blue Jeans. AATCC Review, 5, 23-27.

[10] Dakuri Arjun, D., Hiranmayee, J. and Farheen, N.M. (2013) Technology of Industrial Denim Washing: Review. International Journal of Industrial Engineering \& Technology, 3, 25-34.

[11] Enzymes. http://www.cht-group.com

[12] Enzymes for Textiles. http://www.mapsenzymes.com/Enzymes_Textile.asp

[13] Buschle-Diller, G., Walsh, W.K. and Radhakrishnaiah, P. (1997) Effect of Enzymatic Treatment on Dyeing and Finishing of Cellulosic Fibers: A Study of the Basic Mechanisms and Optimization of the Process Project. C96-Al National Textile Center Annual Report, 31-36.

[14] Ciechańska, D., Struszczyk, H., Miettinen-Oinonen, A. and Strobin, G. (2002) Enzymatic Treatment of Viscose Fibres Based Woven Fabric. Fibres \& Textiles in Eastern Europe, 39, 60-63.

[15] Özdil, N., Özdoğan, E. and Öktem, T. (2003) Effects of Enzymatic Treatment on Various Spun Yarn Fabrics. Fibres \& Textiles in Eastern Europe, 43, 58-61.

[16] Pyc, R., Romanowska, I., Galas, E. and Sójka-Ledakowicz, J. (1999) Hydrolysis of Cellulose Fabrics by Cellulases from Aspergillus IBT-90. Fibres \& Textiles in Eastern Europe, 24, 54-57.

[17] Guzińska, K., Ciechańska, D. and Struszczyk, H. (2002) Investigation of Biosynthesis Process of Cellulolytic Enzymes for Cellulose Fibre Processing. Fibres \& Textiles in Eastern Europe, 37, 77-81.

[18] Onar, N. and Saruşik, M. (2005) Use of Enzymes and Chitosan Biopolymer in Wool Dyeing. Fibres \& Textiles in Eastern Europe, 49, 54-59. 